\section{International Scientific Journal Theoretical \& Applied Science}

\author{
p-ISSN: $2308-4944$ (print) \\ e-ISSN: 2409-0085 (online)
}

Year: 2016

Issue: 3

Volume: 35

Published: $30.03 .2016 \quad$ http://T-Science.org
Lola Abdulhadimovna Kurbonova

$\mathrm{PhD}$, candidate of philosophical sciences, Docent

The "Social sciences" Department

The Andijan State University

Andijan, Uzbekistan

naumenko06@mail.ru

SECTION 30. Philosophy.

\title{
THE ELITIST THEORY OF EDUCATION
}

Abstract: In this article some aspects, questions, problems and principles of the elitist theory of education are considered. Today one of the main tasks of education is preparing of the elites for different spheres and areas of social reality.

Key words: elites, elitist theory of education, professional training, elite universities, elite schools.

Language: English

Citation: Kurbonova LA (2016) THE ELITIST THEORY OF EDUCATION. ISJ Theoretical \& Applied Science, 03 (35): 59-62.

Soi: http://s-o-i.org/1.1/TAS-03-35-10 Doi: crossef http://dx.doi.org/10.15863/TAS.2016.03.35.10

In society has always been and will be necessary in almost every field of the professional elite. These are scientists, politicians, doctors, lawyers, artists, artisans. At each plant there is a working elite, for example, highly skilled toolmakers, turners-station wagons, etc. This is a relatively thin layer of specialists. Under the professional elite are defined as professionals that are made in society samples, the highest levels of professional activity. The creation in society favorable conditions for education and professional elites is a factor of its own dynamics. The education of the professional elite - that is not only higher school and postgraduate education, but also secondary schools, institutions of primary and secondary vocational education. Moreover, these elitist schools do not have to be some kind of "incubators", which would create special conditions for "cultivation of talents", in the words of Mikhail Bulgakov" like pineapples in a greenhouse". As is known, the experience of such "incubators" such as physical-mathematical boarding schools proved unsuccessful.

What is the difference between elite educational institutions from the ordinary?

These differences can consist of, perhaps, ten:

1. The selection system. But not some artificial, namely natural selection. As for the selection of youth for the elite and professional and any other selection of youth the author takes the point of view that does not coincide with, if not common, at least widespread views that people should be selected on the teaching professions with special inclinations and abilities. Perhaps, for some professions of a very limited number is that fair for the artists, painters, pilots, etc. But for most other professions, according to the author, professional selection (in contrast to vocational guidance) is not only not desirable but to some extent dangerous.

On the one hand, there is always the possibility of error in the selection of criteria of professional selection. So for example, for a long time it was believed that an important professional quality driver is a fast reaction. But, as research psychologists, drivers with quick response as time is much more likely to commit accidents than drivers with slow reaction. First count on your quick response, go fast and fall in a traffic accident. Second, knowing their individual characteristics, drive careful. As shown by his detailed research of E. A. Klimov people with different types of nervous system have different, but relatively successfully adapted to a particular professional activity.

On the other hand, from systems theory it is known that any specialization of a complex system, which, in particular, is a man, leads to the narrowing of its functionality. And if people for any professional work to take with certain clearly defined powers, such groups of professionals will be able to successfully perform their function only in certain specific and unchanging constant conditions. Any change of production, economic and social situation to the community would be a disaster.

On the third hand, we know that outstanding achievements in various fields reach the most people, ill-suited to do something "like everyone else" - they seek their own special ways and find them. 
So, obviously, selection is the only way to enable a person: child, boy, girl, adult to Express themselves in activities - in school, in work. To give opportunity to show their potentialities and, perhaps more important for the formation of elite persistence. Perseverance is the most important quality of an elitist personality, and it should be formed from an early age.

A significant role for the selection of youth in elite educational institutions play various forms of preparatory work: correspondence schools, for example, physic-mathematical, Olympiads, training courses, etc.

2. Mode of study - specific, rigid and intense. As history shows, the elite of society is formed in very harsh environmental conditions. For example, in elite British schools, whose graduates traditionally occupy key posts in the government, very strict discipline and very modest, even meager meals, and the bedrooms have no heating and Windows wide open all year round.

3. The teaching of all subjects at a high level of difficulty. In Universities - almost all subjects General and special - at the highest level, the level that is called "aerobatics", when students must be able to walk to the "edge of the unknown", when the student should thoroughly understand: this is science you know, but this is unknown. For example, this task is unsolvable by modern science, this subject area has not been investigated, etc. From the students are required not only know all the rules taught in "regular" schools, but know all without exception exceptions to the rule. This training develops the capacity not to be afraid of any new scientific field, no new activity, no fear of being branded "unprofessional". Just the habit in any situation to go to the library, take tutorials, then scientific monographs, etc. and quickly go "to the edge of the unknown". This is a significant difference between elite academic institutions from "normal".

Moreover, it is important to note that in the process of teaching in an elite school makes no distinction in "degrees of importance" between natural, technical and humanitarian subjects. All are equally important! And this is the most important distinguishing feature of elite educational institutions.

Unfortunately, in the society to the present time, there is quite sustainable misconceptions about the division of science, technical and liberal education; about the division between natural science and humanitarian culture, on their confrontation. But you need to remember that we all live in a special type of culture - technological culture. It is technogenic culture has brought humankind to the line of progress has brought a lot of disasters.

In fact, man today lives in a special man-made world - the bulk of their time people spend in buildings, in cars, subways, paved street, etc. - rarely pulling, that is, on "wild nature", which, incidentally, almost never left, as fields, meadows, forests, etc. are also transformed under the influence of human activity.

But in addition to the external aspects of life in a technological culture, in particular, natural, mathematical and technical Sciences materially alter the mentality of the person. As soon as the Sciences, math, basics of engineering and technology was included in the structure of education, they began changing the way people think, creating critical and analytical rationality. It teaches people to analysis of phenomena, to search for alternative solutions to the relativity of reference systems, definition of concepts and logical operations, to critical perception judgments.

For all that, in no way should belittle the importance of the Humanities. Moreover, in the new socio-economic conditions, requiring each person to be independent in choosing a career or changing it, in search of work or responsibility for their fate, the role of humanitarian education, creating a breadth of vision, flexibility of thinking, citizenship, spirituality is even greater.

Thus, it is necessary to conduct not about the contrast between humanitarian and naturalmathematical, technical education, not about the priority of one over the other, but about finding ways to improve both in their unity and relationship. Moreover, the main drawback of teaching, and humanitarian and natural-mathematical, technical Sciences, in the author's opinion - shared. He is too divisional of detail, which is lost philosophical, ideological essence. It is necessary to restore the former status of the Humanities back to their former functions, namely to serve as a guiding light, illuminating our path and help you choose the right direction in our actions in today is full of uncertainties and surprises of the world. It is necessary to revive the status of naturalmathematical and technical disciplines - as a basis for the formation of the modern scientific worldview.

Natural Sciences and mathematics and technical education professionals should clearly and purely humanitarian spheres. So, for example, the complete absence of teaching of physics to students of conservatories has led to the fact that if in the time of J. S. Bach and W. A. Mozart musicians owned 11 ways orchestral build, then musicians know only two because of this, many works of the old masters are not enforced - they are "sound," because from the point of view of physics (acoustics) they do not correspond to the author's original.

On the other hand, engineering is increasingly involved in the management of science and technology in the solution of various social, economic and environmental problems that increasingly turns to the side of sociology and psychology, thereby developing into the kind of 
humanitarian work. And the emergence and development of computer-based, multimedia makes essentially the information sphere in the humanitarian area.

4. High level of independence in learning activity.

5.Clear professional orientation, formation of professional identity of students when to them before admission - prospective students - and in the process of learning at every lesson, lecture, all extracurricular activities are constantly instilled with the idea: "you are the future scientists", or "you are the future congressmen", or "you are future officers of the General staff" etc. "you are required appropriate behavior, always and everywhere on you a great responsibility, and you need such-and-such and (depending on the profile of elite educational institutions).

6. Methodological training. Recall that the methodology - the doctrine about organization of activity as any, and, in particular, related professional activities - academic, lawyer, doctor, etc. Such preparation is achieved by reading literature on the history of the profession, as well as meetings with high-level professionals who talk about their professional life. In vocational schools to teaching at the senior and specialized courses are employed parttime highly qualified specialists, working in the area - because they are closer to a particular professional life than academic professors.

7. Diverse development.

8. Communication with outstanding people. It is also a feature of elite schools. For example, lectures are delivered by a famous academician. Of course, in didactic lectures regarding normal University Professor usually will be more understandable for students. But the charm of the personality of an eminent scientist, breadth of vision, the scale of his perspective - all this makes an indelible impression on young people, demonstrates the highest level of professionalism, sets "the benchmark" for others to follow.

The same outside the classroom - meetings with prominent people, and of different professions and occupations that are extremely useful on the one hand development, on the other hand - and purely in psychological terms, in terms of identity development among students - they really see that celebrity is not something that is "enormous," "congregation," and what is "regular" living people "and I could be that!".

9. The development of leadership qualities, ability to work in a team. This feature is more characteristic of English and American elite schools and universities. In American and British elitist schools each class, each group is both a sports team and regularly participates in a variety of competitions that stimulates team building. In addition, the "position" of captain of a team of replacement - it in turn perform all team members. In addition, in the educational process in recent years there is widespread these forms of academic work as work in groups, in teams. Including on a competitive basis.

10. Traditions. Elite institution strong in its traditions. First, the school does not become elitist at once, "suddenly." You need at least a few brilliant releases, to earn the "glory" of the elite, and then this glory constantly maintains, "keep the bar". Secondly, over the years formed their own, inner traditions: in the formulation of educational process, mode and so on up to attribution - emblem, anthem, uniforms, students and teachers, etc.

Moreover, strong teacher, teaching staff also formed gradually. And here, apparently, business not only and, probably not so much in higher wages, which often does not happen. It is known that in our traditional special schools - English, physics, mathematics, etc. strong teachers in all subjects, although the salary is the same as everywhere else just in these schools to work more interesting and the teachers willingly go there, and the school has the opportunity for their selection.

Thus, we tried to look at the main features of elitist education, its difference from mass education. Of course, elite schools may not be many, and they may not be big on a contingent - increase the number of students inevitably leads to "lower the bar" known examples of many. But Uzbekistan in its current conditions is essential elite professionals, and elite education needs to develop at all levels. There is needed elite kindergartens, elite schools, elite professional schools and technical schools, and universities, and even elite postgraduate and doctoral studies.

\section{References:}

1. Ashin GK (2005) Problemy jelitnogo obrazovanija V zarubezhnoj sociologii //
Sociologicheskie issledovanija. - 2005. - № 2. pp.87-95. 


\begin{tabular}{l|lrl|l|ll} 
& ISRA (India) & $=\mathbf{1 . 3 4 4}$ & SIS (USA) & $=\mathbf{0 . 9 1 2}$ & ICV (Poland) & $=\mathbf{6 . 6 3 0}$ \\
Impact Factor: & ISI (Dubai, UAE) $=\mathbf{0 . 8 2 9}$ & PUHL (Russia) $=\mathbf{0 . 1 7 9}$ & PIF (India) & $=\mathbf{1 . 9 4 0}$ \\
& GIF (Australia) & $\mathbf{0 . 5 6 4}$ & ESJI (KZ) & $=\mathbf{1 . 0 4 2}$ & IBI (India) & $=\mathbf{4 . 2 6 0}$ \\
& JIF & $\mathbf{1 . 5 0 0}$ & SJIF (Morocco) & $=\mathbf{2 . 0 3 1}$ & & \\
\hline
\end{tabular}

2. Dmitrieva O (2006) Za odnoj partoj s koroljami //Rossijskaja nedelja. - № 3987. 3.02.2006.

3. Kabakchi K (2003) Bol'she, chem prosto shkoly //Obuchenie za rubezhom. - 2003- № 3.

4. Kalishevskij M (2007) Iton - «fabrika dzhentl'menov» //Obuchenie i kar'era. - 2007.№ 1.- pp. 14- 17.

5. Ovchinnikov V (1979) Korni duba // Novyj mir. - 1979.- №. 3-4.

6. Demidenko JS (2005) Perspektivy obrazovanija $\mathrm{v}$ menjajushhemsja mire. - Sociologicheskie issledovanija. 2005. №2.
7. Il'inskij IM (2002) Obrazovatel'naja revoljucija. - Moscow, 2002.

8. Kozlova NN (1994) Bezvkusica mass i vkus intellektualov. - Obshhestvennye nauki i sovremennost'. 1994. № 3

9. Popova GS (2005) Obrazovanie kak process nakoplenija chelovecheskogo i kul'turnogo kapitala. - Social'no-gumanitarnye znanija. 2005. №2.

10. Sohranjaeva TV (2005) Gumanisticheskie orientiry razvitija sistemy obrazovanija. Filosofskie nauki. 2005. №9. 